\title{
Evolution of Japanese ODA 1945-2015: An Analysis
}

\author{
Mohd Ikbal Bin Mohd Huda
}

When Japan emerged as a global economic power, it increased its role in shaping the development of the international community through bilateral and multilateral economic cooperation. The history of Japanese ODA began after gaining its independence from the United States in 1952. Japan began building its ODA program beginning with the payment for war reparations as well as economic and technical cooperation to Asian countries it formally colonised. Until the end of 2015 Japan was still actively adapting its ODA to support the process of socioeconomic development of recipient nations. This article examines the evolution of Japanese ODA from 1945 to 2015. This research is significant in assessing the disbursement trend, the challenges and direction of Japanese ODA in the 21st century. There are five time periods of analysis for the history and evolution of Japanese ODA, firstly being that of Japan's economic restructuring after the war from 1945 to 1953. Throughout this time period Japan received aid from the United States and the World Bank. The second period spans 22 years and is known as the quantitative development and expansion of ODA from 1954 to 1976. This period was also known as the war reparation period. Japan provided foreign assistance in the form of reparation as well as economic and technical assistance to former colonies. The third period was 14 years of systemic expansion from 1977 to 1991. Japan adapted 4 goals during this period in order to increase the amount of aid to recipient countries. The fourth period was the development of ODA philosophy and policy from 1992 to 2002. The global ODA charter was introduced in this period, aimed to explain the Japanese ODA philosophy and promote its aid activities in line with its foreign policy. Japan's role could clearly be established during this period. The last period, challenges in the new era of ODA, began in 2003 until the present time. This was when the ODA charter was re-evaluated for the first time after 11 years on August 23, 2003 in order to shape a more comprehensive global cooperation policy. The re-evaluation of the charter was relevant as the global challenges has increased Japan's role and improved the relation between Japan and its aid recipients.

$$
\begin{aligned}
& \text { 世界は、グローバル化の進展に伴い、相互依存関係を一 } \\
& \text { 層深めてきました。世界とのつながりの中で生きている } \\
& \text { 日本が、人類共同体として、世界の諸課題に取り組んで } \\
& \text { いくことは責務であると同時に、日本の平和と繁栄につ } \\
& \text { ながっています。 }
\end{aligned}
$$

Translation:

Globalization has increased Japan's foreign relations. Living in the international community needs a common responsibility to face the challenges in creating an increasingly complex security and development.

Keywords: ODA, Evolution, Foreign Policy, Cooperation, Global, Japan 


\section{Introduction}

World Official development assistance (ODA) history began through the activities of aid by colonial powers over the territories occupied during the colonial period. According to a report published by the Organisation for Economic Cooperation and Development (OECD) in 1994, the assistance provided by the United States as much as USD5 billion to 16 countries of the European Union through the Marshall Plan, which was signed by Harry Truman, President of the United States on 3 April 1948, was the start of ODA. This scenario explains that the country has advantages in terms of economic assistance (financial) and technical personnel to begin to meet socioeconomic needs of recipient countries.

There is no denying when entities attain developed nation status, contribution to the prosperity of mankind is the role of the country to assist other countries. When Japan emerged as an economic power on the global stage, a role in shaping the international community prosperity through economic cooperation, whether in the form of bilateral or multilateral, has been widespread.

\section{Japan must play a responsible role in the international community as a "peace-fostering nation" to contribute to the peace and prosperity of the world Japan indeed must demonstrate leadership in building peace in the world, become a focal point for the world to gather knowledge and experience in peace-building and to nurture peace-building professionals. ${ }^{1}$}

Armed with a developed country status in the Asian region, Japan is actively adjusting its ODA to support the process of socioeconomic development in each of the recipient countries. Japan sees global problems such as ethnic and religious conflicts, armed conflicts, violence, suppression of human rights, democracy, environmental problems, infectious diseases, poverty, famine, refugee crises and natural disasters, are among the important issues that need to be dealt with immediately. Significantly, such problems and conflicts have the potential creating threat to the international community.

\section{Tokyo's definition of the concept has been based on its post-World War II values of pacifism, emphasis on developmental aid, and more recently the norms of human security. Its consolidation-of- peace approach has a strong ODA component with considerations of "human security" (the survival and welfare of individuals rather than the state) and the eradication of poverty. ${ }^{2}$}

Japan provides ODA in three different forms to meet the needs of each recipient country. There are two types of ODA channelled bilaterally and multilaterally. Bilateral ODA can be divided into three types, namely yen loans, grants and technical assistance. While multilateral ODA disbursed to aid mechanisms include both international organizations such as the United Nations and the international financial institutions like the World Bank.

\footnotetext{
${ }^{1}$ Lam Peng Er, Japan's Peace Building Diplomacy in Asia: Seeking a more active political role, Singapore: Markono Print Media Pte Ltd, 2009, pp. 12.

${ }^{2}$ Lam Peng Er, Japan's Peace Building Diplomacy in Asia: Seeking a more active political role, Singapore: Markono Print Media Pte Ltd, 2009, pp. 15.
} 


\section{History of Japanese ODA}

The history of Japanese ODA ${ }^{3}$ began after independence from the United States in 1952. Nine years after independence, the Overseas Economic Cooperation Fund (OECF) was established as an agency responsible for implementing the distribution of yen loan assistance under the ODA program in 1961. Japan's status as one of the main contributors can be seen through the effects of economic transformation after the end of the Second World War around 1980. Based on experience adapting to the ODA, Japan managed to revive the economy in 1950 and began to pay war reparations to the countries of Asia which has been colonized. Burma was among the first countries to sign the compensation payments in 1954 amounted to USD200 million, followed by the Philippines in 1956 amounted to USD550 million, Indonesia in 1958 totalled USD223 million and South Vietnam in 1959 totalled USD39 million. Whereas for economic and technical cooperation, Burma also became the first country to sign the agreement in 1963, totalling USD140 million, South Korea in 1965 totalled USD300 million, Malaysia and Singapore in 1967 with a total of USD8.17 million. Although Mongolia was the last country to sign the treaty in 1977 , it amounted to USD18 million.

Starting with the payment of compensation, as well as economic and technical cooperation, it evolved into a form of ODA. The assistance proved to show a significant improvement from 1960 until 1989 with the help of more than USD8.9 billion. However, Japanese policy makers focus on the development of quantitative versus qualitative improvement in foreign aid. After the end of the Cold War, Japan introduced new guidelines in the distribution of aid, namely Four ODA Guidelines in 1991 and ODA Charter in 1992. The implementation of the guidelines allows Japan to promote the distribution of aid to the universal values of human rights, development of physical capital and human capital development. However, Japan's assistance received less positive assessment at the international level because of the distribution of ODA loans exceeds the amount of other assistance.

In order to improve the effectiveness of ODA towards the process of socio-economic development of the recipient countries, Japan joined the Development Assistance Group (DAG) in 1961, which was later changed to the Development Assistance Committee (DAC) in 1962. There is no doubt that participation in DAC Japan is the first step in the OECD for financial support, expertise and technical assistance to third world countries. Japanese ODA has increased consistently from USD70.4 million in 1956 to USD390.6 million in 1967 and USD1.263 billion to USD2.844 billion between the years 1969-1973. Increasing the amount of aid provides an opportunity for Japan to actively promote the ODA program to establish the Japan International Cooperation Agency (JICA) as the agency responsible for coordinating the technical cooperation program and provide grant assistance in 1974.

In addition, the San Francisco Peace Treaty ${ }^{4}$ and the Colombo Plan ${ }^{5}$ are also important to analyse two aspects of Japanese involvement in the distribution of ODA to other

\footnotetext{
${ }^{3}$ Cameron M. Otopalik, "Japan's Overseas Development Assistance: Assessing Conformance With Shifting Priorities,"International Journal of Politics and Good Governance, Vol. 1, Issue 1.1, pp. 1. Hidetomi Oi and Junko Mimaki, "Policy Transitions in Japanese ODA for Disaster Risk Reduction in Developing Countries," Asian Journal of Environment and Disaster Management (AJEDM), Vol. 2, Issue 3, pp. 1. Mitsuya Araki "Japan's Official Development Assistance: The Japan ODA Model That Began Life in Southeast," Asia-Pacific Review, Vol. 14, Issue. 2, pp. 19. Hidekazu Tanaka, "International Cooperation and National Consensus Building," Quarterly Journal of Public Policy \& Management, Mitsubishi UFJ Research and Consulting, pp. 82.

${ }^{4}$ Mitsuya Araki "Japan's Official Development Assistance: The Japan ODA Model That Began Life in Southeast," Asia-Pacific Review, Vol. 14, Issue 2, pp. 20.

${ }^{5}$ Junichi Yamada, Japanese Official Development Assistance In Southeast Asia, ISIS Kuala Lumpur, 1998, pp. 5. Hugh Patrick, "Legacies of Change: The Transformative Role of Japan's Official Development Assistance in its Economic Partnership with Southeast Asia," Discussion Paper No. 54, Discussion Paper Series APEC Study Center, Columbia University, pp. 5. Mitsuya Araki “Japan's Official Development Assistance: The Japan ODA
} 
countries. The San Francisco Peace Treaty was approved by Japan to pay remittance in the form of compensation and economic cooperation with countries that have been colonized or occupied during the war. Under the San Francisco Peace Treaty, Japan has signed an agreement with the countries of the former colony before paying compensation in 1951 and among the earliest countries to enter into agreements to indemnify and economic cooperation are Indonesia, Thailand, Laos, Cambodia, Philippines, Vietnam, Myanmar, Singapore, Malaysia and South Korea as stated previously.

The signing of the Colombo Plan on October 6, 1954, was the beginning of the involvement of Japanese aid to foreign countries to carry out the mission of global development for the international community. ${ }^{6}$ Even in the early stages of channelling aid, while Japan still owes the World Bank, Japan has proven that the concept of self-help towards development is very important in the process of modernizing the country towards a more complex life. After 36 years of channelling ODA, Japan managed to settle the debt of the World Bank borrowed in 1953 for the Tokaido Shinkansen and Tomei Expressway. ${ }^{7}$ The following year, Japan became the largest contributor of ODA for six consecutive years until 1996 and the fifth largest in 2010. ${ }^{8}$ According to a report published by Gaimusho and JICA in 2015, Japan has provided ODA to more than 190 countries of the Asian region that has the strategic potential for Japan to be the dominant inheritance. ${ }^{9}$ Japan also became the largest aid contributor to other international organizations such as the Asian Development Bank (ADB), Asian Productivity Organization (APO), the Industrial Development United Nations (UNIDO) and the African Development Fund (ADF) until 2008. ${ }^{10}$ Table 1 shows the overall commitment of Japanese ODA in 1991-2014 amounted to USD257,428 million. The largest number of commitments that have been distributing aid is in the year 2000 amounted to USD13,508 million while overall average aid in the next 24 years is USD10,726.16 million.

With an overall average USD10,726.16 million each year, the assistance provided was viewed as conducive to the financial resources to help the world community to address the challenges of globalization that exists between the communications infrastructure, transport, health and infectious diseases. ODA, among which was adapted as an instrument of foreign policy of Japan, is seen as very significant to support the agenda of peace and stability in recipient countries through assistance in the form of financial, technical and humanitarian aid. ${ }^{11}$

\footnotetext{
Model That Began Life in Southeast," Asia-Pacific Review, Vol. 14, Issue 2, pp. 20. Hidekazu Tanaka, "International Cooperation and National Consensus Building," Quarterly Journal of Public Policy \& Management, Mitsubishi UFJ Research and Consulting, pp. 82.

${ }^{6} \mathrm{http}: / /$ www.japanesestudies.org.uk/articles/2008/FuruokaKato.html.

${ }^{7}$ Fumitaka Furuoka, New challenges for Japan's Official Development Assistance (ODA) policy: Human rights, democracy and aid sanctions. Kota Kinabalu: Penerbit UMS, pp. 69.

${ }^{8}$ Hidekazu Tanaka, "International Cooperation and National Consensus Building," Quarterly Journal of Public Policy \& Management, Mitsubishi UFJ Research and Consulting, pp. 81. Hugh Patrick, "Legacies of Change: The Transformative Role of Japan's Official Development Assistance in its Economic Partnership with Southeast Asia," Discussion Paper No. 54, Discussion Paper Series APEC Study Center, Columbia University, pp. 7.

${ }^{9}$ http://www.africa-asia-confidential.com/special-report/id/14/Japan_International_Cooperation_Agency .

${ }^{10}$ Rui Faro Saraiva, "Japanese Foreign Policy and Human Security in the Context of an Emerging New Global Order" Journal of Conflict Transformation \& Security Vol. 3, Issue 1, pp. 48. Bronson Percival, "JapanSoutheast Asia Relations:Playing Catch-up with China," Comparative Connections, A Quarterly E-Journal on East Asian Bilateral Relations, http://csis.org/files/media/csis/pubs/0603qjapan seasia.pdf, pp. 3.

${ }^{11}$ Cameron M. Otopalik, "Japan's Overseas Development Assistance: Assessing Conformance With Shifting Priorities," International Journal of Politics and Good Governance, Vol. 1, Issue 1.1, pp. 1. Hidetomi Oi and Junko Mimaki, "Policy Transitions in Japanese ODA for Disaster Risk Reduction in Developing Countries," Asian Journal of Environment and Disaster Management (AJEDM), Vol. 2, Issue 3, pp. 1. Mitsuya Araki "Japan's Official Development Assistance: The Japan ODA Model That Began Life in Southeast," Asia-Pacific Review, Vol. 14, Issue 2, pp. 19. Hidekazu Tanaka, "International Cooperation and National Consensus Building," Quarterly Journal of Public Policy \& Management, Mitsubishi UFJ Research and Consulting, pp.
} 
Table 1: Total Japanese ODA 1991-2015

\begin{tabular}{|c|c|}
\hline Year & $\begin{array}{c}\text { Amoun } \\
\text { (USD Million) }\end{array}$ \\
\hline 1991 & 10,952 \\
\hline 1992 & 11,151 \\
\hline 1993 & 11,259 \\
\hline 1994 & 13,239 \\
\hline 1995 & 14,489 \\
\hline 1996 & 9,439 \\
\hline 1997 & 9,358 \\
\hline 1998 & 10,640 \\
\hline 1999 & 12,162 \\
\hline 2000 & 13,508 \\
\hline 2001 & 9,847 \\
\hline 2002 & 9,283 \\
\hline 2003 & 8,880 \\
\hline 2004 & 8,922 \\
\hline 2005 & 13,146 \\
\hline 2006 & 11,136 \\
\hline 2007 & 7,679 \\
\hline 2008 & 9,362 \\
\hline 2009 & 9,470 \\
\hline 2010 & 11,045 \\
\hline 2011 & 11,086 \\
\hline 2012 & 10,605 \\
\hline 2013 & 11,582 \\
\hline 2014 & 9,188 \\
\hline 2015 & - \\
\hline
\end{tabular}

Source: http://www.mofa.go.jp

The success of Japan dominated sectors including technology, automotive, electronics and shipbuilding, while being able to produce high-tech products and consumer goods in the optimal amount to be exported on a large scale, it is also an advantage for Japan to improve the effectiveness of ODA at the global level. Gaimusho also argued that in order to adapt comprehensive cooperation, it requires expertise and ideas that are important to ensure optimal results. With the success and expertise possessed, Japan is deserving of the "thought leader" status to share experience with countries receiving ODA to progress towards universal achievement.

82. Rui Faro Saraiva, "Japanese Foreign Policy and Human Security in the Context of an Emerging New Global Order" Journal of Conflict Transformation \& Security Vol. 3, Issue 1, pp. 36-39. Emilio de Miguel, "Japan And Southeast Asia: From The Fukuda Doctrine To Abe's Five Principles," UNISCI Discussion Papers, Ministerio de Asuntos Exteriores y Cooperación (MAEC), pp. 113. 


\section{Evolution of the Japanese ODA}

There are five time periods ${ }^{12}$ of analysis for the history and evolution of Japanese ODA, firstly being that of Japan's economic restructuring after the war from 1945 to 1953 . The second period spans 22 years and is known as the quantitative development and expansion of ODA from 1954 to 1976. The third period was 14 years of systemic expansion from 1977 to 1991 . The last period, is known as the challenges in the new era of ODA, began in 2003 until the present time.

\section{Economic Restructuring after the War Period 1945-1953}

The period 1945-1953 has seen a shortage in some aspects, especially, the transition of Japan's status from receiving to pre-channelling aid country. Secondly, the payment of war reparations motive as part of the process of delivering aid. This is because the development and history of Japanese ODA payments were seen as irrelevant within the period as Japan was still one of the receiving countries. However, the status of which provides a significant advantage and the impact on Japan's foreign aid policy is "understanding" the situation of the countries that receive aid. Understanding these views has an impact on aid delivery mechanisms during prechannelling from 1945 until 1953.

However the payment of war reparations cannot be seen as foreign aid because there are significant differences between ODA and payment of war reparations in the context of "purpose". For example, foreign aid is channelled to assist the process of socio-economic development due to a lack of domestic capital, while compensation is to bear the damage inflicted or otherwise. This explains that the compensation is not for the purpose of channelling ODA distribution of foreign aid during the recovery period of the war, but can be seen as a method of developing Japanese ODA. However, different interpretations by the DAC and the OECD recognize the compensation as part of development assistance and is seen as among the reasons why the Japanese government does not distinguish between ODA and payment of damages. This situation explains the scenarios that economic cooperation can be interpreted as covering all aspects of compensation and assistance, including countries that do not demand war reparations that are also eligible to receive foreign aid.

\section{Quantitative Development and Expansion of ODA 1954-1976}

With the aim to help improve the competitiveness of global socio-economic standards, Japanese cabinet has approved a resolution to join the Colombo Plan on October 6, 1954 . $^{13}$ Japan began to circulate in the form of technical assistance and trainers to foreign countries as a mission to integrate with the international community. Japan also signed an agreement on the payment of damages and economic cooperation with the Philippines, Indonesia, Vietnam, Laos, Cambodia, Thailand, and Malaysia, Singapore and South Korea in 1955-1960 and all damages were successfully settled in 1976. Starting with the payment of compensation to countries that have been colonized, it evolved into a form of ODA. The development of ODA was viewed as an assurance of Japan's national interests in Southeast Asia as well to restore Japan's bilateral ties with the countries involved.

\footnotetext{
${ }^{12}$ Hugh Patrick, "Legacies of Change: The Transformative Role of Japan's Official Development Assistance in its Economic Partnership with Southeast Asia," Discussion Paper No. 54, Discussion Paper Series APEC Study Center, Columbia University, pp. 5-6.

${ }^{13}$ http://www.mofa.go.jp/policy/oda/cooperation/anniv50/pamphlet/progress 1.html.
} 
The historical background of Japan's financial assistance began as providing war reparations and economic cooperation to countries in East Asia, along with the basic policy of providing cooperation for countries that had close economic links to Japan. Tokyo focused on countries in East Asia and those that had close economic links because the government felt it had a debt to pay for Japan's actions in the 1930s and 1940s, and Japan was still classified as a developing country, which inclined it to view aid as a tool to develop the economy and Japanese companies. ${ }^{14}$

The arguments above explains the important scenario that begins with the payment of war reparations, and it developed into a more comprehensive aid. Analysis found that the assistance provided is intended to assist socio-economic development of the recipient countries and the development of Japanese companies. In addition to this, the analysis also found that rapid economic growth during the 1960s encourages Japan to channel more aid to the international community. According to statistics published by Gaimusho in 2010, the number of Japanese ODA disbursed since 1954 to 1964 amounted to USD115.8 million and commitments increased tenfold to USD1.11 billion in $1976 .{ }^{15}$ One of the factors that led to the successful implementation of the current ODA payment, this period was the establishment of OECF in 1961 to arrange a yen aid loan which is then converted to JICA in 1974.

\section{Systemic Expansion 1977-1991}

To increase efficiency and diversify the types of assistance under the ODA program, Japan had been using five targets ${ }^{16}$ to promote ODA since 1977 (Table 2). This period is important because Japan successfully paid all compensation payments to former colonies due to rapid economic growth between 1900 and 1979 as stated. This situation allows Japan to formulate a strategy to expand the distribution of ODA to other regions, including regions of Africa, the Middle East and Latin America. The Middle East region ${ }^{17}$ is seen as essential to Japan's crude oil resources. The continued importance of the region to Japan's domestic economy, is reflected in the sharp rise of ODA from $0.8 \%$ in 1972 to $24.5 \%$ in 1977 and over $30 \%$ in 1991. The importance of the area also led Japan to adjust to some new support programs such as disaster relief in 1973, grants for cultural activities in 1975 and global food aid in 1977.

Table 2 shows five targets to promote ODA in the period of systematic expansion. In 1980, Gaimusho listed four main targets in terms of humanitarian assistance, namely security, health and economic continuous development. Significantly, all the focus is the foundation of ODA charter which was introduced in 1992 and remains the new ODA charter in 2003. The analysis found that the five strategies tailored were very significant when Japan emerged as the country's largest ODA donor countries to address the assistance provided by the United States in 1989.

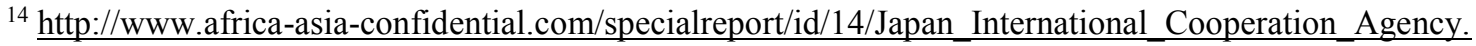

${ }^{15} \mathrm{http}$ ://www.mofa.go.jp/policy/ODA/cooperation/anniv50/pamphlet/progress1.html.

${ }^{16} \mathrm{http}$ ://www.mofa.go.jp/policy/oda/cooperation/anniv50/pamphlet/progress2.html.

${ }^{17}$ Kamahori Miki, "Doing What's Possible on Time," The Japan Journal, 2007, http://www.japanjournal.jp/tjje/show art.php?INDyear=07\&INDmon=08\&artid=157a9c2b6ece02303f53f6c703 ebece7\&page $=4$.
} 
Table 2: Five Systematic Strategies 1977-1991

\begin{tabular}{|l|l|}
\hline \multicolumn{1}{|c|}{ Strategy } & \multicolumn{1}{c|}{ Total Aid } \\
\hline $\begin{array}{l}\text { The first target of ODA in } \\
1978-1980\end{array}$ & $\begin{array}{l}\text { Total ODA in 1977 amounted to USD1.42 billion } \\
\text { double by 1980. }\end{array}$ \\
\hline $\begin{array}{l}\text { The second target of ODA } \\
\text { in 1981-1985 }\end{array}$ & $\begin{array}{l}\text { Total ODA in 1981-1985 increased to USD10.68 } \\
\text { billion }\end{array}$ \\
\hline $\begin{array}{l}\text { The third target of ODA } \\
\text { in 1986-1992 }\end{array}$ & Total ODA in 1986-1992 exceeded USD40 billion. \\
\hline $\begin{array}{l}\text { The forth target of ODA } \\
\text { in 1988-1992 }\end{array}$ & Total ODA in 1986-1992 increased to USD50 billion. \\
\hline $\begin{array}{l}\text { The fifth target of ODA in } \\
\text { 1993-1997 }\end{array}$ & $\begin{array}{l}\text { Total ODA in 1993-1997 increased to USD70-75 } \\
\text { billion. }\end{array}$ \\
\hline
\end{tabular}

Source: http://www.mofa.go.jp/policy/oda/cooperation/anniv50/pamphlet/progress2.html

The consistency of distribution by Japanese trend has sparked a huge phenomenon when it successfully defended its position as the largest contributor of ODA from 1991 to $2000 .{ }^{18}$ According to statistics published by the DAC in 2011, the number of Japanese ODA issued is more than $20 \%$ of total aid to all members DAC.

\section{Development of ODA Philosophy and Policy 1992-2002}

During this period Japan had provided a total of USD13 billion in the Gulf War from 1990 to 1991. Distribution of aid provides opportunities to engage in the context of democracy and protection of human rights internationally. According to the annual report of Japan's ODA in 1996, the early development of the communications infrastructure must be emphasized if developing countries want to achieve socio-economic growth. However, to achieve this, developing countries require large amounts of development funds and ODA is seen as a complement to the flow of funds needed by developing countries to implement such communication projects. Meanwhile the repayment of the bond required is to encourage the recipient countries toward improving self-help productivity in the socio-economic competitiveness globally. ${ }^{19}$

In order to ensure the long-term effects of the aid disbursed, Japan has set four key focus points of ODA in 1991, the first, ODA is banned for military activities. Second, ODA can only adapt to the socio-economic development of the recipient countries. Third, ODA could also be used to finance environmental preservation projects. Fourth, ODA needs to be adjusted for humanitarian activities and culture. According to a report published by Gaimusho in 2010, all the focus points are rated as highly effective and in unique position ${ }^{20}$ as Japan attaches great importance to support developing countries towards economic progress.

During the ODA policy and philosophy enhancement period, aid was extended to the African region to help address issues such as health, education, water, poverty, civil war,

\footnotetext{
${ }^{18}$ Hidekazu Tanaka, "International Cooperation and National Consensus Building," Quarterly Journal of Public Policy \& Management, Mitsubishi UFJ Research and Consulting, pp. 81.

${ }^{19}$ Cameron M. Otopalik, “Japan's Overseas Development Assistance: Assessing Conformance With Shifting Priorities," International Journal of Politics and Good Governance, Vol. 1, Issue. 1.1, pp. 5-7. Hugh Patrick, "Legacies of Change: The Transformative Role of Japan's Official Development Assistance in its Economic Partnership with Southeast Asia," Discussion Paper No. 54, Discussion Paper Series APEC Study Center, Columbia University, pp. 3.

${ }^{20} \mathrm{http}: / /$ www.mofa.go.jp/policy/oda/cooperation/anniv50/pamphlet/progress3.html.
} 
famine and disease. ${ }^{21}$ In order to deal with "threats" in the region as well, Japan took the initiative in organizing the Tokyo International Conference on African Development $(\text { TICAD })^{22}$ in 1993, 1998, 2003, 2008 and 2013 to promote ODA. By continuing in organizing TICAD, Japan's ODA was to become among the biggest developing aid assistance to the African region since 1993 and consistently remained so until 2013. The analysis also found that Japan has set a target to increase ODA to the African region from an average of USD 1 billion in 2003 to 2007 to USD 2 billion during TICAD IV. Although the target is not reached, with the distribution of aid by USD1.8 billion in 2011 to the African Development Bank, it depicts the significant scenario that Japan is committed to continue to assist the socio-economic projects in the region.

Japan has provided ODA to the African region worth USD392 million in 1970 to 1979 , USD1.2 billion in 1980 to 1989, USD1.563 billion in 1990-1999, USD1.668 billion in 2000 to 2009 and USD2 billion in 2010-2013. Based on the analysis of the ODA distribution period spanning 43 years, projects involving social sectors such as water, education and health became the dominant recipient of $37.5 \%$ followed by $34.2 \%$ in economic sectors involving projects such as energy, fisheries, and banking.

In addition to addressing issues such as poverty, infectious diseases and AIDS in the African region, Japan announced the Global Issues Initiative (GII) in Cairo, Egypt in 1994, a year after the first TICAD. Okinawa Infectious Diseases Initiative (IDI) ${ }^{23}$ during the KyushuOkinawa G8 Summit in July 2000 is seen as Japan's commitment to continue to address this crisis. Implementing IDI seemed rational as the resolution to prevent HIV / AIDS, tuberculosis and malaria. ${ }^{24}$ For example, although the disease cannot be fully addressed in Kenya, there are signs of improvement after the implementation of various health programs by JICA and NonGovernmental Organisations (NGO). Ongoing initiatives by NGO and JICA explained that health programs remains a major challenge in Kenya due to the fact that $6.3 \%$ or 1.5 million are HIV positive until the end of $2009 .^{25}$

\section{Challenges in the New Era of ODA 2003-2015}

Japanese ODA in the new era is seen as a challenging period. There are several important aspects of this period include the ODA Charter, revised for the first time on August 29, 2003 after 11 years of operation in order to improve the effectiveness of aid towards becoming more comprehensive. Second, collaboration with implementing ODA program agencies under the New JICA came into effect on October 1, 2008 to improve the effectiveness of aid to recipient countries. Three agencies ${ }^{26}$ which have a dominant influence in channelling of Japanese ODA are JICA, the Japan Bank for International Cooperation (JBIC) and Gaimusho. The three agencies are directly under the ODA program that has variety

\footnotetext{
${ }^{21} \mathrm{http}: / / w w w . a f r i c a-a s i a-c o n f i d e n t i a l . c o m / s p e c i a l$ report/id/14/Japan_International_Cooperation_Agency .

${ }^{22}$ http://www.mofa.go.jp/policy/other/bluebook/1989/1989-3-8.htm .

${ }^{23}$ http://www.mofa.go.jp/policy/oda/evaluation/FY2003/text-pdf/okinawa.pdf, http://www.sciencedirect.com/science/article/pii/S1471492206003126 and http://joicfp.or.jp/eng/enews/2004 nov/08-IDIOkinawaNeedPhoto.php.

${ }^{24} \mathrm{http}: / /$ www.mofa.go.jp/policy/oda/cooperation/anniv50/pamphlet/progress3.html .

${ }_{25} \mathrm{http} / /$ www.jica.go.jp/kenya/english/activities/activitiy01.html and http://www.jica.go.jp/english/publications/j-world/c8h0vm00008mqace-att/1401.pdf.

${ }^{26}$ Hugh Patrick, "Legacies of Change: The Transformative Role of Japan's Official Development Assistance in its Economic Partnership with Southeast Asia," Discussion Paper No. 54, Discussion Paper Series APEC Study Center, Columbia University, pp. 4-5. Hadi Soesastro, "Sustaining East Asia's Economic Dynamism: The Role of AID," PRI-OECD Research Project, CSIS, Indonesia, pp. 17.
} 
functions and roles before New JICA established. ${ }^{27}$ JICA is one of bilateral development agencies in the world that are responsible for delivering technical assistance to recipient countries. JBIC is responsible for paying the loan while Gaimusho is responsible for distributing grants.

The strategy of combining Gaimusho, JICA and JBIC under the New JICA in 2008 is very important in improving the effectiveness of aid towards becoming more comprehensive. For example, the annual report in 2007 on the ground by Gaimusho explains the quality of Japanese ODA to be criticized as weak as yen loans (JPY901.8 billion) still take precedence over technical assistance (JPY325.8 billion) and grants (JPY154.2 billion). Hence, under the New JICA, the mutual agreement reached by the three agencies is that the loan was reflected by the receiving country that the application requires more funds for the development of socio-economic infrastructure. The situation describes two scenarios, the first of which is important, still retains the concept of New JICA requests the recipient country when delivering aid. Second, the alliance also influences the direction of foreign policy that affect the evolution of Japan between Japan's ODA from 1954 until now. Cooperation for over seven years is seen to improve the quality of assistance based on the effectiveness of individual projects implemented in the recipient country.

During this period, one of the initiatives undertaken in Tokyo is to announce the distribution of greater assistance to the African region, the Middle East and Asia during TICAD III and Japan-ASEAN Commemorative Summit in 2003. Japan took an early initiative by announcing a grant of USD 5 billion to Iraq and Afghanistan to host a conference of world peace during TICAD III in Madrid. The aid is seen as very important for infrastructure development including communications, transportation, education and health where in Afghanistan it is at its lowest after the end of the war. Japan is aiming to make Afghanistan as a model of development and security in the future as Japan makes the Asian region as a model of economic development.

The analysis found that this objective has a very strong foundation for post-conflict assistance and should definitely be implemented immediately in order to avoid conflicts from becoming more serious. Adaptation of Japanese ODA plays an important role in some countries to reach the level of post-conflict political process, including Afghanistan and Iraq. Afghanistan is an example to the developing countries involved in post-conflict politics and democratization of Afghanistan has given a new image to the nation and the Islamic world. If there are cases in which problems in Afghanistan cannot be solved, it will most certainly affect other regions such as Africa. In the event that the funds are used to resolve conflicts, development assistance must be marginalized. Thus Japan's commitment to the nation state visits among the best mechanism to promote the democratization of the world.

During this period, the Japanese have also adopted the strategy of "Medium-Term Strategy for Overseas Economic Cooperation" together with Gaimusho on April 2005 until March 2008 aims to ensure ODA loans be more effective by identifying areas that have the potential and prioritize these areas. Despite the increase in the amount of aid to Africa and the Middle East region, the Asian region ${ }^{28}$ remains the dominant recipient of aid which was up to $86 \%$ of Japan's total ODA from USD 13,126 million in $2005 .{ }^{29}$ Indonesia led the largest ODA recipient list for a total assistance of USD 1,223 million, followed by Vietnam at USD602.64 million for the Southeast Asian region.

\footnotetext{
${ }^{27}$ http://www.jica.go.jp/english/news/field/2008/081001.html.

${ }^{28}$ Hugh Patrick, "Legacies of Change: The Transformative Role of Japan's Official Development Assistance in its Economic Partnership with Southeast Asia," Discussion Paper No. 54, Discussion Paper Series APEC Study Center, Columbia University, pp. 3-10.

${ }^{29}$ http://www.mofa.go.jp/mofaj/gaiko/oda/shiryo/jisseki.html.
} 
Three priority sectors through such strategy are the transport sector by $34 \%$, electricity and gas $30 \%$ and the public sector by $22 \%$. For example, a country prone to earthquakes such as Indonesia and the countries with the restructuring of the socio-economic weakness between Pakistan and Vietnam have extended ODA programs aimed at supporting the restructuring following the natural disaster and improve the environment and social institutions of the country concerned. According to a report published Gaimusho in 2006, 34\% of the total aid received by Vietnam in 2005 have been allocated for projects to eradicate poverty and infrastructure development projects. Whereas aid totalling JPY52.9 billion was used for transportation projects with the construction of Tanjung Priok Access Road II in Indonesia in 2004 and 2005. ${ }^{30}$

Apart from focusing on the Asian region as the main focus for the distribution of aid, collaboration with the African Development Bank (AfDB) and enhanced Help Private Sector (EPSA) was implemented after Japan mooted the strategy during the conference of the G8 in Gleneagles in July 2005 to assist the socio-economic development in the African region. Through EPSA strategies, initiatives by JBIC to encourage the co-financing scheme with the AfDB. The first ODA loan totalling JPY9.6 million was used to upgrade road transport projects like Bamako-Dakar in Senegal while the rural electrification project amounted to JPY17.31 million and water supply projects amounted to JPY54.12 million have been executed in Tunisia in 2005.

Despite over 60 years of achievements and experience, the Japanese ODA still faces criticism and demands were made to revise Japan's assistance policy to suit the conditions in the recipient country. The criticism comes as Japan has more large amounts of ODA to allocate to the main trading partner, while the needs of poor and weak countries are not taken into consideration. Researchers have found that it is not difficult to assess the problem if the characteristics of Japan ODA are made with reference to a number of circumstances which have occurred, including in Asia. For example, countries like China, India, Indonesia, Philippines and Thailand among the five that received the most dominant Japanese ODA to 2015. Analysis of the distribution of aid is very important to assess the trend of Japan's ODA to the issue of monopoly by the five countries that had advantages in some areas, including size area, labour, raw materials and markets. All the potential has attracted the interest of Japan to continue providing assistance for the common interest. It is undeniable that the issue of Japanese ODA monopoly still exists to this day by making Laos as a comparative example. Laos is a country with an area of around $236.800 \mathrm{~km} 2$ with a population of 6.8 million. Although Laos is listed as countries that receive Japanese ODA, the amount received is less than five countries due to the lack of labour, markets and raw materials.

Laos has received Japanese ODA loan assistance JPY51.9 million to build a hydroelectric dam on the Nam Ngum in 1974. Although the level of industrialization and urbanization in the country is very low, the project succeeded in producing electricity from the Nam Ngum hydroelectric dams. The success of these projects enables Laos to export electricity from the dam to Thailand to face power shortages caused by the rapid industrial sector. The project's success led to a hydroelectric dam in Laos seeking assistance to build several more dams. However, the application was not considered because of the continued absence of a guarantee by Laos. Although hydroelectric dam project provides an opportunity for Laos to develop the industrial sector, depending on only electricity exports does not provide a strong guarantee compared with other industries in the neighbouring countries. These are the risk factors that affect the distribution of aid to Laos until today.

\footnotetext{
${ }^{30}$ http://www.id.emb-japan.go.jp/oda/en/odaprojects loan.htm, http://www.id.emb japan.go.jp/oda/en/projects/loan/odaprojects loan 2004 9.htm and http://www.meti.go.jp/meti lib/report/2011fy/E001632.pdf.
} 


\section{Direction of Japanese ODA}

Based on the evolution of the four-term ODA debated, the direction of Japanese ODA can be divided into three, namely first, bilateral ODA and multilateral cooperation between the mechanisms adapted to improve regional cooperation and make Japan the dominant power in Asia. ${ }^{31}$ The lack of local capital to move socio-economic development projects have opened up space for Japan to expand assistance to help the process of socio-economic development, especially among the Association of Southeast Asian nations (ASEAN) countries. The importance of the engagements undertaken is the best model to measure the implementation of Japanese ODA in the region.

The trend to deliver assistance in the transition to other areas also explains the direction of Japanese ODA. For example, in order to achieve peace and human progress, Japanese ODA is not only focused on the Asian region but also for other regions such as the Middle East and Africa. ${ }^{32}$ Starting with TICAD I in 1993, followed by TICAD II in 1998, TICAD III in 2003, TICAD IV in 2008 and TICAD V in 2013 showed that Japan is committed to continue to assist the process of development in other regions such as Africa. ${ }^{49}$ Development assistance are important to the region in the argument by Gaimusho;

ODA has been very effective throughout Africa and contributes to
the positive developments that have occurred in Africa during the
last ten years...Africa is very grateful for the level of interest showed
by Japan towards African development and Japan is recognized as
one of the leading providers of ODA to Africa. ${ }^{33}$

However, the "concern" among which should be analysed over time to see trends in the distribution of ODA (yen loans) for the African region, particularly with regard to debt management capacity by the recipient countries. Please note that the foreign debt of African countries have been revoked or cancelled under the initiative Heavily Indebted Poor Countries (HIPCs) at the beginning of the 21st century. There is also an urgent need to extend debt relief to HIPCs that have been marginalized in the globalization process due to the state foreign debt burden that is difficult or impossible to pay. If the role and contribution of Japan to debt relief for over 20 years were analysed, of course Japan plays an important role in international initiatives on debt relief for the countries and the developing countries in the African region. The analysis found that, Japan has cancelled more than JPY340 billion (USD3 billion) of debt by the 27 recipient countries categorized as the poorest country since 1978 .

There is another "concern" factor regarding the position of Japan as a national distributor of ODA to the African region. Based on statistics for the years 2010-2013, Japan ranked fifth behind the United States, France, Britain and Germany. While Japan actively lobbying and promoting the implementation of the HIPCs debt initiative to the other G7 members, it is important to look at the trend over the next 5-10 years will be influenced by several factors, including the region's potential and global competition. This was obvious

\footnotetext{
${ }^{31}$ Takahashi, M. "The Ambiguous Japan: Aid Experience and Notion of Selfhelp," in Lehman H.P. (ed.) Japan and Africa: Globalization and Foreign Aid in the 21st Century, Oxon and New York: Routledge, 2010, pp. 3970 .

32 Takahashi, M. "Nihon-no Tai-Africa Enjo Gaiko no Hensen: 'Hannosei’ and Seijiteki-ishi no Ketsujo" ("A Historical Account on Japan's Aid Diplomacy towards Africa: 'reactiveness' and Lack of Political Will") Kokusai Mondai no.591, 2010, pp. 14-27, Sato, M. "An Historical Analysis of Japan's Aid Policy in Africa," in Lehman H.P. (ed.) Japan and Africa: Globalization and Foreign Aid in the 21st Century, Oxon and New York: Routledge, 2010.

${ }^{33}$ http://www.mofa.go.jp/policy/oda/cooperation/anniv50/seminar0411.txt.
} 
during TICAD IV held in Yokohama in June 2013 when Japan announced the involvement of the private sector to the region for the next five years. It is undeniable that the African region also needs an injection of funds from the private sector and public-private partnerships to take advantage of any investment. During TICAD IV, Japan has announced the commitment of USD46 billion and USD14bilion assistance from the commitment of the private sector.

Second, the quality assistance factor which also explains the Japanese ODA policy. Quality of the assistance effectiveness provided by bilateral and multilateral levels to each project is measured by socioeconomic policies implemented. Significantly, the recipient countries not only have the chance to learn all the technology and expertise that is distributed, but also pave the way towards sharing of development experience, adapted by other countries.

\begin{abstract}
"Based on Japanese experience, we can extend the good quality cooperation to developing countries. But at the same time the developing countries, which experienced development, can share their experience with other countries. They can utilize their experience to help other developing countries. That is the idea of South-South cooperation and Japan can effectively promote such South-South cooperation. This is another pillar of the future direction of Japanese ODA." 34
\end{abstract}

The arguments above also stressed the importance of South-South cooperation in terms of technical and economic cooperation to be seen as a mechanism to promote the effective development by learning and sharing of technical knowledge among developing countries and developed countries. South-South cooperation, especially in the African context is actively developing in the field of agriculture and the private sector. This initiative is in line with the action plan adopted at TICAD II Conference in which the Japanese government has expressed a desire to support South-South cooperation to the General Assembly of the United Nations to fund Technical Cooperation Among Developing Countries (TCDC). Based on the first TICAD conference held in 1993, the development program of the United Nations has been actively working with the Japanese government to reduce poverty by addressing the socio-economic problems in Africa. Concrete steps for development in Africa under the "Tokyo Agenda for Action" was adopted in 1998 during TICAD II conference. The action sets the basic principles of cooperation and aspects of ownership by African countries, who led development projects in Africa. As part of this development approach, more emphasis on the effectiveness of the Asia-Africa cooperation is made to implement a more important cooperation. The partnership emphasizes the importance of private sector development for socio-economic growth, strengthening of governance as the basis for development, the importance of conflict prevention and post-conflict reconstruction.

Japan's role in South-South cooperation is relevant because of the experience after the Second World War and has been the recipient country. In the ODA Charter, Japan stated that it will actively promote South-South cooperation with developing countries and countries in Asia and other regions. Japanese aid to Africa increased and TICAD IV is seen as an important moment in relations between Japan and Africa. According to the annual report of TICAD IV, published in 2008 and a report in 2009, showing a total of USD1.75 billion was distributed by Japan in socio-economic development in the African region. Even in 2012, the number of Japanese ODA to Africa is the region increased to USD0.9 billion, USD1.8 billion in 2011. Many countries in Africa have experienced conflict and civil war since independence. The situation led to Japan stressing on the importance of security and stability as the foundation of

${ }^{34}$ http://www.mofa.go.jp/policy/oda/cooperation/anniv50/seminar0411.txt. 
economic development through the TICAD. After the end of the conflict in the early $21 \mathrm{st}$ century, Japan strengthened assistance to ensure the consolidation of peace, to prevent conflicts from recurring. Japanese assistance included the conflict prevention, humanitarian assistance, reconstruction of social infrastructure, rehabilitation and maintenance of security coordination with the TICAD partners. According to a report published Gaimusho, during 1993-2011, the energy and infrastructure sectors which received assistance amounting to $24 \%$, with $10 \%$ of the water sector, the education sector by $6 \%, 3 \%$ of the health sector, the cultural sector by $2 \%$ and sectors another $47 \%$.

Some examples of regional development projects, infrastructure and transport that has been carried out is the construction of the Chirundu bridge on the border between Zambia and Zimbabwe in the Trans Africa with the help of a grant that was completed in 2002, construction of the bridge in the Southern Corridor between Mali and Senegal with the help of grants and completed in 2011, the restoration of $322 \mathrm{~km}$ of roads in Ethiopia with the help of grants and $98.2 \mathrm{~km}$ of road rehabilitation in Ghana. Along with the energy sector, examples of projects that have been implemented is a project for rural electrification and Jebba power station hydroelectric project in Nigeria with the help of a grant which was completed in 2010 and 2014, projects to improve the electrical system supply in the capital of Sierra Leone with grant aid, which was completed in 2010, the rural electrification project in Uganda with a grant that was completed in 2010, rural electrification in Ghana with the help of a grant that was completed in 2008 and more. For the agricultural sector, Japan assists in the developing agricultural potential and to achieve food security in Africa. Japan supports the Comprehensive Africa Agriculture Development Program (CAADP) by promoting the cultivation of rice in Africa since TICAD II. The Joint African Rice Development (CARD), which was established in TICAD IV aims to double rice production in Sub-Saharan Africa in a decade from 14 million tons in 2008 to 28 million tons in 2018. As of 2010, the number has reached about 18.4 million tons. Some examples of cooperation and projects which have been carried out between shows that Japan is fully committed to promote assistance to the African region to assist the socioeconomic development in the region.

The third direction is to support the activities of global peace through ODA. ${ }^{35}$ It is undeniable that experiencing a resurgence of Japan after the devastation of the tragedy of the Second World War can be a model of universal peace. ${ }^{36}$ Recovery miracle in a short period of 20 years shows that human civilization is not static and frozen as it develops over time. The change towards advancement or decline depends on the implementation of the strategy. History has shown that the work ethic and discipline that is highlighted by the development of Japanese society induces great phenomenon when successfully implemented into the world economic hegemony only in the last 20 years. Armed with the experience of dynamic development, Japan has been adjusted through ODA. As a country that has provided assistance, Japan made the experience as an important asset when ODA requires only be used as a domestic capital to drive socio-economic development projects and banning its use for military activities. Japan for immediate development of communication infrastructure and public facilities is important for creating comfort and safety to the community, creating economic opportunities and improving competitiveness in the global strengthening of the structure.

\footnotetext{
${ }^{35}$ Rui Faro Saraiva, "Japanese Foreign Policy and Human Security in the Context of an Emerging New Global Order” Journal of Conflict Transformation \& Security Vol. 3, Issue. 1, pp. 36-39. Cameron M. Otopalik, “Japan's Overseas Development Assistance: Assessing Conformance With Shifting Priorities," International Journal of Politics and Good Governance, Vol. 1, Issue. 1.1, pp. 2-18. Lam Peng Er, Japan's Peace Building Diplomacy in Asia: Seeking a more active political role, Singapore: Markono Print Media Pte Ltd, 2009, pp. 112.

36 Takahashi, M. "The Ambiguous Japan: Aid Experience and Notion of Selfhelp," in Lehman H.P. (ed.) Japan and Africa: Globalization and Foreign Aid in the21st Century, Oxon and New York: Routledge, 2010, pp. 3970 .
} 


\section{Conclusion}

The analysis of the 70-year evolution of Japanese ODA leaves five significant effects. First, Japan reacted actively in addressing various forms of threats, crises and global challenges through its ODA program. Notably, global problems which could trigger a crisis between the suppression of human rights, poverty, ethnic and religious conflicts, famine, refugee crises, infectious diseases, terrorism, environmental problems and armed conflict. ODA adapted to be important for Japan to experience the history of the country's development and the advancement of technology to work with the international community to be more comprehensive in addressing global issues.

Second, three forms of assistance provided were intended to meet the needs of different development in each recipient country. More importantly, all three forms of assistance are based on the duality of ODA and the concept of self-help. Adaptation of ODA that has pioneered the development of each country received towards socio-economic growth more sustainable. Through this concept, Japan has made the historical experience of development and economic progress as a model to the recipient countries. For example, after World War II, products made in Japan do not concern the international community toward the United States and Britain. However, with the development strategy to strengthen the sector, finance and production company Japan successfully listed among the influential economic hegemony at global level. Although the workmanship exhibited by the Japanese managed to put products including automotive previously known to be lukewarm like Honda, Nissan, Toyota, Honda, Yamaha and Suzuki now dominate global markets and successfully compete with products from major US allies such as General Motors, Ford and Chrysler.

Third, the analysis also shows the trends, challenges and the direction of Japanese ODA in the 21st century. ODA traits that prohibit assistance to military activities rather than just adapting to socio-economic development, projects of environmental conservation and cultural and humanitarian activities are preserved. It can be seen based on the adaptation and the role of Japanese ODA in some countries reached the level of post-conflict political process, including Afghanistan and Iraq.

Fourth, in addition to placing priority assistance to the Asian region, the distribution of ODA extended to other regions, including Africa and the Middle East. Fifth, no doubt the assistance provided by the hegemonic economic impact of long-term investment will benefit both parties. Sixth, the assistance provided guarantees "security" against the national interest of Japan to acquire raw material resources of the recipient countries. 